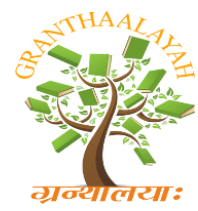

INTERNATIONAL JOURNAL OF RESEARCH GRANTHAALAYAH

A knowledge Repository

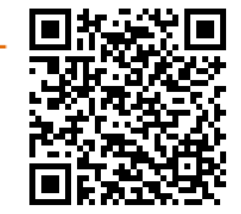

Social

\title{
GOODWILL OF LIBRARY USERS AND ITS IMPACT ON SERVICES:
}

\section{A STUDY}

\author{
Dr. S. M. Rokade *1
}

${ }^{*}$ University Librarian, Gondwana University, Gadchiroli 442 605, Maharashtra, INDIA

\begin{abstract}
The paper succinctly describes the concept of goodwill, nature and value, intellectual capital resources, viewpoints of library goodwill, perspectives and User's goodwill and its impacts on functioning of library, services and working staff. It reveals that $64.70 \%$ goodwill generates among the users through maintaining good relations by the library staff, $64 \%$ rendering quality services, 92\% leadership, promptness, and skillul policy, 84.70 by creating well behaviour with various types of readers, $47.05 \%$ library staff should be punctual in timing with attachment and affinity in public library readers as they comes under the umbrella of grass root users. The goodwill generates $80.83 \%$ intangible asset which invisible and $92.50 \%$ develop publicity of library automatically. It was concluded that goodwill totally depends on the behaviour and prompt services to the users to save their times.
\end{abstract}

Keywords:

Goodwill, Library/KRC, Users, intangible assets.

Cite This Article: Dr. S. M. Rokade, “GOODWILL OF LIBRARY USERS AND ITS IMPACT ON SERVICES: A STUDY” International Journal of Research - Granthaalayah, Vol. 4, No. 1 (2016): 43-49.

\section{INTRODUCTION}

In changing scenario there is major role of intellectual capital in global economy and in this new economic environment, data, information and knowledge are considered to be essential factors for decision making. The various types of intellectual capital is provided by the Libraries/ Knowledge Resource Centers and the main aim and object of these centers are to collect, process and disseminate the conventional and nonconventional much needed information to the users as per their needs and requirement. The professionals in library science have to follow new workflows, roles, modernize information uses, need of users, social relation and contacts considering the future few year's developments to cater to the informational needs of the users as in recent years this transition process is not easy and is rarely smooth. The concept of Library without wall, Virtual, Paperless, Digital, Video, Online and Lending Library is coming to you and Web Library has taken the place of conventional libraries. 
The users are the soul of libraries and their goodwill plays a major role from both side i.e. library and users to improve the services and use of library. Goodwill is an intangible asset that is listed collaterally in the balance sheet of library and goodwill although intangible assets have no physical form; their presence increases the services and importance of library. Goodwill is loosely divided into personal, intellectual and business goodwill. Together they reflect the value of the time and energy which spent creating and growing the library services. The book value of goodwill is the difference but in some cases, the value of goodwill can exceed that of the physical assets.

It is not easy service to acquire the goodwill of the users for librarian. It depends on the availability of adequate infrastructure, conventional and non-conventional collection development, well trained and qualified human resources modernize services, and facilities, skill, leadership, working skill, occasion awareness and behaviour of librarian and staff with users, status of rendering information services, collaboration with other institutes and interest. Considering the major role and significance of goodwill of library users and its impact on the use of services the study of academic, research, special and public library users was carried out by collecting and analyzing data to fulfill the aims and object of the study .

\section{OBJECTIVES OF THE STUDY}

- To know the concept of library goodwill

- To observe the users of various types of libraries/KRC

- To verify the users goodwill about Library/KRC

- To find out the various types of approaches of library goodwill

- To search an impact of goodwill on library/KRC

\section{SCOPE OF THE STUDY}

The scope of the study was limited within the jurisdiction of only two districts i.e. Gadchiroli and Chandrapur in backward and tribal region of eastern Maharashtra .The study was mainly concerned with the goodwill of users of libraries and its impact on library services and therefore the scope covered users of university, college, institute, high school, primary and public libraries comprising Agricultural, Non Agricultural, and professionals like arts, science, commerce, law, engineering, medical, and pharmaceuticals faculties libraries.

Table 1: Group of Libraries

\begin{tabular}{|c|c|c|c|c|c|c|}
\hline \multirow[t]{3}{*}{ Group } & \multirow[t]{3}{*}{ Nature of Libraries } & \multirow[t]{3}{*}{ Category of Libraries } & \multicolumn{4}{|c|}{ Number of Libraries } \\
\hline & & & \multicolumn{2}{|c|}{ Urban } & \multicolumn{2}{|c|}{ Rural } \\
\hline & & & $\frac{\text { Tota }}{1}$ & $\frac{\text { Surveye }}{\mathrm{d}}$ & $\frac{\text { Tota }}{1}$ & $\frac{\text { Surveye }}{\mathrm{d}}$ \\
\hline \multirow[t]{3}{*}{$\mathrm{A}$} & Academic Libraries & University-Gadchiroli & 01 & 01 & 000 & $\overline{00}$ \\
\hline & & College-Gadchiroli & 15 & 15 & 074 & 24 \\
\hline & & Chandrapur & 18 & 18 & 130 & 39 \\
\hline $\bar{B}$ & Research Libraries & Krishi Vidyanan Kendra & 01 & 01 & 000 & 00 \\
\hline $\mathrm{C}$ & Special Libraries & Agricultural Libraries & 02 & 02 & 000 & 00 \\
\hline $\mathrm{D}$ & School Libraries & High-school \& Primary & & & & \\
\hline
\end{tabular}




\begin{tabular}{|l|l|l|l|l|l|l|}
\hline E & $\begin{array}{l}\text { District Libraries } \\
\text { Public Libraries }\end{array}$ & $\begin{array}{l}\text { District-Gadchiroli and } \\
\text { Chandrapur }\end{array}$ & 02 & 02 & 000 & 00 \\
& & $\begin{array}{l}\text { Public - Chandrapur } \\
\text { Gadchiroli }\end{array}$ & 15 & 15 & 162 & 48 \\
& & SEARCH/LBP & 00 & 00 & 002 & 02 \\
\hline F & NGO Libraries & Total Libraries & 66 & 66 & 493 & 149 \\
\hline
\end{tabular}

Source: website SEARC- Shodhgram LBP- Lok Biradari Prakalp

Table 2: Cadre of Library Users

\begin{tabular}{|c|c|c|c|}
\hline Group & Nature of Libraries & Category of Libraries & Cadre of Library Users \\
\hline A & Academic Libraries & $\begin{array}{l}\text { University -Gadchiroli } \\
\text { College-Gadchiroli } \\
\text { Chandrapur }\end{array}$ & $\begin{array}{l}\text { Academic staff, Teachers, Scientist, } \\
\text { Research scholars, Students, other } \\
\text { users }\end{array}$ \\
\hline $\mathrm{B}$ & Research Libraries & Krishi Vidyanan Kendra & $\begin{array}{lll}\text { Scientist, } & \text { Research } & \text { scholars, } \\
\text { Students } & & \end{array}$ \\
\hline $\mathrm{C}$ & Special Libraries & Agricultural Libraries & $\begin{array}{l}\text { Academic staff, Teachers, Scientist, } \\
\text { Research scholars, Students, } \\
\text { Industrialists, Farmers, other users }\end{array}$ \\
\hline $\mathrm{D}$ & School Libraries & High-school \& Primary & Students, Teachers \\
\hline $\mathrm{E}$ & $\begin{array}{l}\text { District Libraries } \\
\text { Public Libraries }\end{array}$ & $\begin{array}{l}\text { District-Gadchiroli and } \\
\text { Chandrapur } \\
\text { Public-Chandrapur } \\
\text { Gadchiroli }\end{array}$ & $\begin{array}{l}\text { All kinds of People, Lawyers, } \\
\begin{array}{l}\text { Doctors, Teachers, } \\
\text { Student, } \\
\text { Businessman. Farmers, } \\
\text { Hawkers, Rickshaw drivers }\end{array}\end{array}$ \\
\hline $\mathrm{F}$ & NGO Libraries & SEARCH/LBP & Local persons, concerned users \\
\hline
\end{tabular}

Source: website SEARC- Shodhgram LBP- Lok Biradari Prakalp

\section{REVIEW OF LITERATURE}

Choudhary et.al (2011), a practical and rather simple example for explaining the goodwill produced by a library is provided by Choudhary et.al. Let us assume that the library expenses for acquiring printed and electronic resources are $\mathrm{R}$, with $\mathrm{S}$ being the total library expenses (E) are $\mathrm{E}=\mathrm{R}+\mathrm{S}$. A desired outcome for the library would be the goodwill, denoted by $\mathrm{G}=\mathrm{SO}-\mathrm{E}$, where $\mathrm{SO}$ is the successful outcomes and $\mathrm{E}$ the total expenses for achieving them.

Sidoroko and Yang (2011), recently a number of papers have commented on the goodwill created by library operations and services, while others make suggestion for the creation of library goodwill (Walden 2006)

Marilla D.Svinicki and Barbara A. Schwartz (1998) Positive motivators are less powerful, but have desirable side effects of long term goodwill and positive affect towards the resources available in the library.

Cam Merritt (2015)"Goodwill" on a company's balance sheet represents value that the company gained when it acquired another business but that it can't assign to any particular asset of that 
business. Goodwill doesn't always affect a company's net income, but if that goodwill becomes "impaired," the effect can be substantial.

\section{METHODOLOGY}

The richness of library is totally based on the optimum use of library and services and it was found in a pilot survey that the goodwill of library users plays crucial role and considering this the content "Goodwill of Library Users and its Impact on Services" was selected for the study. The cluster sampling method was used to collect the data and particular groups were organized as the entire population of users was unclear. The randomly sample assigned for study so that various library users participants better represent the larger group from which they're drawn.

The data was collected through personal visits, interview, and observation, discussion and Online questionnaire comprising infrastructures, collection development with e-resources; modernize services, human resources, and facilities users' goodwill towards library, types of approaches of library goodwill and impact of user's goodwill on libraries.

\section{DEFINITION OF “LIBRARY GOODWILL”}

At Goodwill, we are committed to respect, integrity, trust and operational excellence. We believe in the power of work.

Marshall Field (American Businessman, 1834- 1906) "Goodwill is the one and only asset that competition cannot undersell or destroy."

Hayn and Hughes (2006) Goodwill is viewed as an asset by the market and the decline in the value of goodwill is used by investors to value the firm as a whole. Therefore, goodwill represents the value and performance of an entire entity.

Rokade S.M.(2015) Library Goodwill is an intangible asset that arises as a result of acquisition of one Library or Knowledge Resource Center by another for a premium value. The value of a Library's quality services, close, good and active relation with users, concrete users base, proper, skillful, supportive and good staff relations and availability of modernize techniques and technology represent goodwill. Goodwill is not a physical asset like buildings or equipment but it is considered an intangible asset. Goodwill is very valuable for the development of library and is the assets of library balance sheet but it is very difficult to calculate the cost or price. It has also a invisible power to moor or mar the institute when it became negative.

\section{RESULT AND DICUSSION}

\subsection{USER'S GOODWILL TOWARDS LIBRARY}

Table 3: Users of Libraries and their value in support of goodwill

\begin{tabular}{|c|c|c|c|c|c|}
\hline \multirow[b]{2}{*}{ Group } & \multirow[b]{2}{*}{$\underline{\text { Nature of Libraries }}$} & \multirow[b]{2}{*}{$\underline{\text { Classes of Users of Libraries }}$} & \multicolumn{3}{|c|}{ Nature \& Value of goodwill } \\
\hline & & & $\begin{array}{l}\text { Approache } \\
\underline{\mathrm{s}}\end{array}$ & $\frac{\text { Total }}{340}$ & $\frac{\text { Value }}{\%}$ \\
\hline $\mathrm{A}$ & Academic Libraries & Academic staff, & Good & 220 & 64.70 \\
\hline
\end{tabular}




\begin{tabular}{|c|c|c|c|c|c|}
\hline & & $\begin{array}{l}\text { Scientist, Research scholars, } \\
\text { Students, other users }\end{array}$ & relation & 340 & \\
\hline \multirow[t]{2}{*}{ B } & \multirow[t]{2}{*}{ Research Libraries } & \multirow{2}{*}{$\begin{array}{l}\text { Scientist, Research scholars, } \\
\text { Students }\end{array}$} & \multirow{2}{*}{$\begin{array}{l}\text { Quality } \\
\text { services }\end{array}$} & 32 & \multirow[t]{2}{*}{64.00} \\
\hline & & & & 50 & \\
\hline \multirow[t]{2}{*}{$\overline{\mathrm{C}}$} & \multirow[t]{2}{*}{ Special Libraries } & \multirow{2}{*}{$\begin{array}{l}\text { Academic staff, } \text { Teachers, } \\
\text { Scientist, Research scholars, } \\
\text { Students, } \\
\text { Farmers, other users }\end{array}$} & \multirow{2}{*}{$\begin{array}{l}\text { Leadership } \\
\text { Promptness } \\
\text { Skillful } \\
\text { policy }\end{array}$} & 46 & \multirow[t]{2}{*}{92.00} \\
\hline & & & & 50 & \\
\hline \multirow[t]{2}{*}{$\mathrm{D}$} & \multirow[t]{2}{*}{ School Libraries } & \multirow[t]{2}{*}{ Students, Teachers } & \multirow{2}{*}{$\begin{array}{l}\text { Well } \\
\text { behaviour }\end{array}$} & 288 & \multirow[t]{2}{*}{84.70} \\
\hline & & & & 340 & \\
\hline \multirow[t]{2}{*}{$\mathrm{E}$} & \multirow[t]{2}{*}{$\begin{array}{l}\text { District Libraries } \\
\text { Public Libraries }\end{array}$} & \multirow{2}{*}{$\begin{array}{l}\text { All kinds of People, Lawyers, } \\
\text { Doctors, Teachers, Student, } \\
\text { Businessman. Farmers, } \\
\text { Labors, Hawkers, Rickshaw } \\
\text { drivers }\end{array}$} & \multirow{2}{*}{$\begin{array}{l}\text { Punctual in } \\
\text { timing } \\
\text { Attachment } \\
\text { affinity }\end{array}$} & 160 & \multirow[t]{2}{*}{47.05} \\
\hline & & & & 340 & \\
\hline \multirow[t]{2}{*}{$\mathrm{F}$} & \multirow[t]{2}{*}{ NGO Libraries } & \multirow{2}{*}{$\begin{array}{l}\text { Local persons, concerned } \\
\text { users }\end{array}$} & \multirow{2}{*}{$\begin{array}{l}\text { Quality } \\
\text { collection }\end{array}$} & 22 & \multirow[t]{2}{*}{44.00} \\
\hline & & & & 50 & \\
\hline
\end{tabular}

Source: Questionnaire and communication

\section{OBSERVATION}

It was observed from the table 1 that $64.70 \%$ library users opined that goodwill generates among the users through maintaining good relations by the library staff, 64\% rendering quality services, $92 \%$ leadership, promptness, and skillful policy, 84.70 by creating well behaviour with various types of readers, $47.05 \%$ library staff should be punctual in timing with attachment and affinity in public library readers as they comes under the umbrella of grass root users, $44 \%$ readers of NGO libraries says that there should be quality collection with modernize techniques in the library.

\section{VIEWPOINTS OF LIBRARY GOODWILL}

A library's goodwill is an interesting concept with many different aspects relating to intellectual capital. The cadre wise survey of libraries was carried out to observe the various kinds of viewpoints that shape a library's goodwill and exists as an intangible resource in a library.

- Infrastructure

- Collection Development

- Financial Resources

- Human Resources

- Library Services

- Modernize Facilities for Users

- Coordination and cooperation of Library staff

- Users' satisfaction

Table 4: Intellectual capital resources

\begin{tabular}{|l|l|}
\hline Related directly to the library & Related indirectly to the library \\
\hline Programmes of advertising campaign & Information policy makers \\
\hline Reputation of library & Information regulators \\
\hline
\end{tabular}




\begin{tabular}{|l|l|}
\hline User relationship, loyalty, trust with library & Broadcast license \\
\hline User training programme & Unemployment, economy \\
\hline Information suppliers and publishers & Mass media \\
\hline Information Literacy Programme & University and Research organization \\
\hline Adult Education Programme & Shareholders agreement \\
\hline Library and Information networks & Royalty agreements \\
\hline Personality contacts and partnership & Special interest groups \\
\hline Public relation & Societies \\
\hline Technology sharing agreements & National Government contracts \\
\hline Web enterprises, user relationship & Regulatory approvals \\
\hline
\end{tabular}

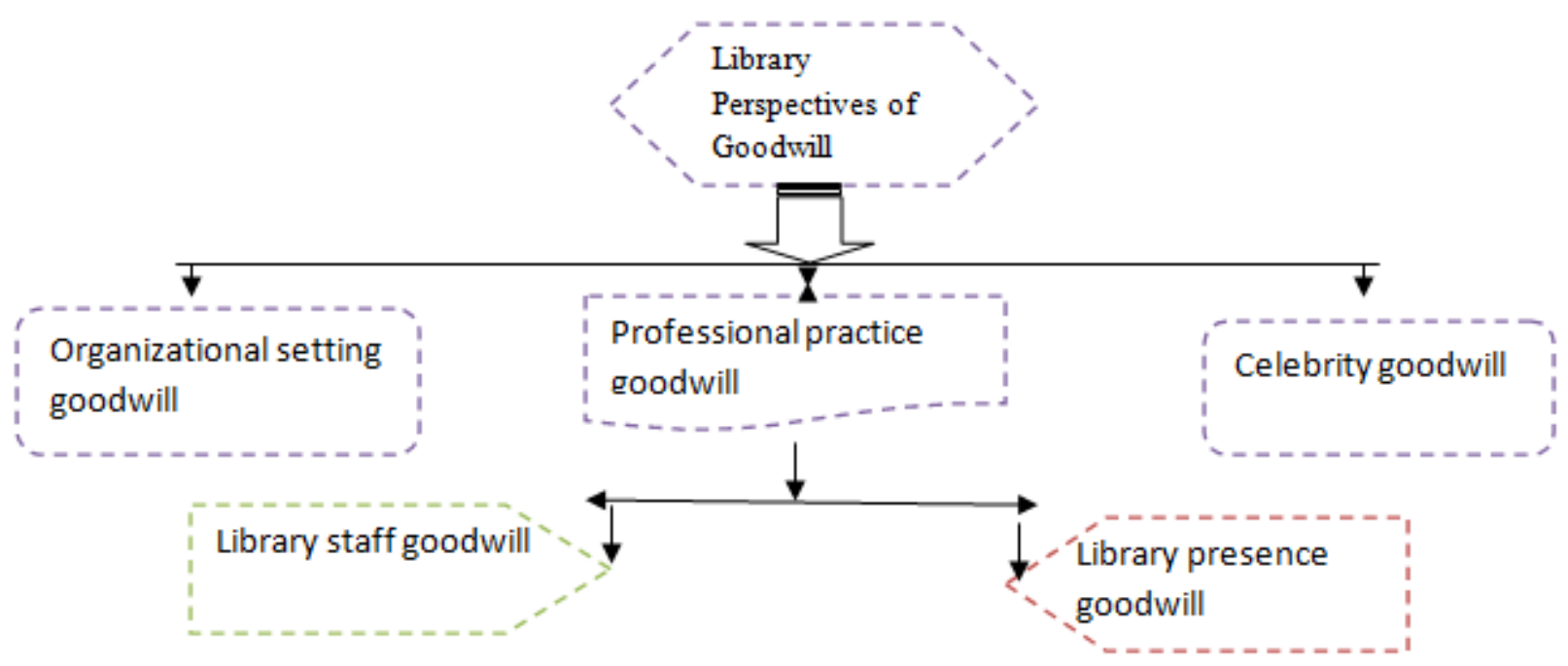

Figure 1: Library Perspectives of Goodwill

\subsection{USER'S GOODWILL AND ITS IMPACTS ON LIBRARY}

Table 5: Users goodwill and its impact

\begin{tabular}{|c|c|c|c|c|c|}
\hline \multirow[b]{2}{*}{$\frac{\text { Grou }}{\underline{p}}$} & \multirow[b]{2}{*}{ Nature of Libraries } & \multirow[b]{2}{*}{ Nature of impact } & \multicolumn{3}{|c|}{ Value of impact } \\
\hline & & & $\begin{array}{l}\text { Total } \\
150 \\
\end{array}$ & $\underline{\underline{\text { Valid }}}$ & $\begin{array}{l}\text { Value } \\
\underline{\%}\end{array}$ \\
\hline A & Academic Libraries & intangible asset & $\overline{120}$ & 97 & $\overline{80.83}$ \\
\hline B & Research Libraries & valuable for development & 40 & 35 & 87.50 \\
\hline $\mathrm{C}$ & Special Libraries & $\begin{array}{l}\text { encourage to improve services } \\
\text { support to increase users }\end{array}$ & 40 & 27 & 67.50 \\
\hline $\mathrm{D}$ & School Libraries & full utilization of resources & 100 & 77 & 77.00 \\
\hline $\mathrm{E}$ & $\begin{array}{l}\text { District Libraries } \\
\text { Public Libraries }\end{array}$ & $\begin{array}{l}\text { Goodwill is the reward of } \\
\text { services of library and staff } \\
\text { support to increase users }\end{array}$ & 140 & 121 & 86.42 \\
\hline
\end{tabular}




\begin{tabular}{|l|l|ll|l|l|l|}
\hline F & NGO Libraries & $\begin{array}{l}\text { develop } \\
\text { automatically }\end{array}$ & publicity & 40 & 37 & 92.50 \\
\hline
\end{tabular}

Source: Questionnaire, internet, mobile and verbal communication

\section{OBSERVATION}

It was observed from the table 1 that $80.83 \%$ users expressed their views that goodwill is the intangible asset of library, $87.50 \%$ shows valuable for development, $67.50 \%$ presents to encourage and to improve library services and support to increase number of users, $77 \%$ utilize full available resources of library. The $86.42 \%$ users opined that Goodwill is the reward of services of library and staff and support to increase quantity of users for reading and $92.50 \%$ suggested to develop publicity of library automatically.

\section{CONCLUSIONS AND RECOMMENDATIONS}

It was concluded that Goodwill is an intangible asset that is listed collaterally in the balance sheet of library and goodwill although intangible assets have no physical form; their presence increases the services and importance of library. The goodwill generates among the users through maintaining good relations by the library staff, rendering quality services, good leadership, promptness in services and facilities, and skillful policy, by creating well behaviour with various types of readers.

\section{REFERENCES}

[1] Hayn, Carla and Hughes, J Patricia.. Leading Indicators of Goodwill Impairment. Journal of Accounting, Auditing and Finance, 2005, SSRN: http://ssrn.com/abstract.

[2] Marilla D.Svinicki \& Barbara A. Schwartz. . Designing Instruction for Library Users: A Practical Guide, Marcel Dekker, Inc. New York , USA 1998 ,76 https://books.google.co.in/books.

[3] Petros Kostagiolas. Managing Intellectual Capital in Libraries, Chandos Pub. Oxford, 2012, .71-72 https://books.google.co.in/books. 